\title{
Vegetation, phosphorus, and dust gradients downwind from a cattle feedyard
}

\author{
RICHARD W. TODD, WENXUAN GUO, BOBBY A. STEWART, AND CLAY ROBINSON
}

Authors are Soil Scientist, USDA-ARS Conservation and Production Research Laboratory, Bushland, Tex.; former Research Assistant; Director, Dryland Research Institute; and Assistant Professor; West Texas A\&M University, Canyon, Tex.

\section{Abstract}

A native shortgrass pasture downwind from a 25,000-head beef cattle feedyard near Bushland, Tex. degraded after the feedyard was stocked in 1970. Objectives were to determine pre-1970 vegetation, quantify current vegetation, and describe changes in vegetation, soil $P$ and dust deposition with distance from the feedyard. Pre-1970 vegetation was documented with published measurements. In 2000, plant cover was quantified using 600 quadrats. Soil $\mathbf{P}$, conserved in the local soil, was measured in soil samples from 119 locations. Dust was collected at 12 locations. From 1966-1972, cover was 18.8\% blue grama [Bouteloua gracilis (H.B.K.) Lag. ex Griffiths] and 7.4\% buffalograss [Buchloe dactyloides (Nutt.) Engelm.]; the 2 species comprised $95 \%$ of vegetation cover. In 2000 , perennial grass (75-99\% blue grama) cover averaged $3.7 \%$ at $<150 \mathrm{~m}$ from the feedyard, and increased to $28 \%$ at $>525 \mathrm{~m}$ from the feedyard. Conversely, annual grass (67\% Hordeum pusillum Nutt.) and annual forb [72\% Kochia scoparia (L.) Schrad.] covers were $49 \%$ and $35 \%$ nearest the feedyard and decreased to $9 \%$ and $1 \%$, respectively, at $>\mathbf{5 2 5} \mathrm{m}$. Over a similar distance, soil $\mathbf{P}$ decreased from 75 to $17 \mathrm{mg} \mathrm{kg}^{-1}$. Dust deposition rate decreased with distance from the feedyard. Manure dust contribution to total dust ranged from negligible to $89 \%$. It was estimated that $20-30 \mathrm{~kg} \mathrm{~N} \mathrm{ha}^{-1}$ year $^{-1}$ were deposited over 30 years to areas nearest the feedyard. Changes in vegetation and soil $P$ were greatest at $<500 \mathrm{~m}$ from the feedyard. Vegetation and soil $P$ were near values expected for shortgrass prairie at $>500 \mathrm{~m}$ downwind from the feedyard. The pattern of vegetation, soil fertility, and dust deposition gradients strongly suggested that the feedyard was the primary cause of the observed changes, although a direct causal link could not be established, and other factors, such as grazing, could have contributed to the observed changes.

Key Words: shortgrass steppe, vegetation change, plant nutrients, nutrient transport, feedyard dust, soil phosphorus

The High Plains region of the Texas Panhandle and surrounding states is a mosaic of irrigated and dry cropland and grassland. More than half the agricultural land area is grassland, and most of that is native rangeland. Shortgrass prairie dominates most native rangeland, especially on upland clay and silty clay soils. Blue grama [Bouteloua gracilis (H.B.K.) Lag. ex Griffiths] and buffalograss [Buchloe dactyloides (Nutt.) Engelm.] are the major species of the southern High Plains shortgrass prairie.

Manuscript accepted 5 Sept. 03

\section{Resumen}

Un pastizal nativo de zacates cortos localizado viento abajo de un corral de engorda de 25,000 cabezas de ganado cercano a Bushland, Tex., degradada después de que la engorda fue poblada con ganado en 1970. Los objetivos fueron determinar la vegetación existente antes de 1970 , cuantificar la vegetación actual y describir los cambios en vegetación, $\mathbf{P}$ del suelo y deposición de polvo a través de un gradiente de distancia a partir de los corrales de engorda. La vegetación existente antes de 1970 se documentó con mediciones publicadas. En el 2000 , la cobertura vegetal se cuantificó usando 600 cuadrantes, el P del suelo, conservado en el suelo local, fue medido en muestras de suelo de 119 sitios y el polvo se colectó en 12 localidades. De 1966 a 1972, la cobertura vegetal fue de $18.8 \%$ de "Blue grama" [Bouteloua gracilis (H.B.K.) Lag. ex Griffiths] y 7.4\% de "Buffalograss" [Buchloe dactyloides (Nutt.) Engelm.]; las dos especies conformaron el $95 \%$ de la cobertura. En el 2000 , la cobertura de zacates perennes (75-99\% "Blue grama") promedió $3.7 \%$ en distancias menores de $150 \mathrm{~m}$ de los corrales de engorda y se incrementó a $\mathbf{2 8 \%}$ en distancias mayores de $\mathbf{5 2 5} \mathrm{m}$ de los corrales. Contrariamente las coberturas de zacates anuales $(67 \%$ Hordeum pusillum Nutt.) y hierbas anuales [72\% Kochia scoparia (L.) Schrad.] fueron de $49 \%$ y $35 \%$ cerca del corral y disminuyeron a $9 \%$ y $1 \%$, respectivamente, en distancias mayores de $525 \mathrm{~m}$. En distancias similares, el $\mathbf{P}$ del suelo disminuyó de 75 a $17 \mathrm{mg} \mathrm{kg}^{-1}$. La tasa de deposición de polvo disminuyó con la distancia del corral de engorda. La contribución de polvo de estiércol al polvo total varió de cantidades inapreciables a $89 \%$ del total. Se estimó que, en los 30 años de operación de los corrales, en las áreas cercanas de a ellos se depositaron entre $20-30 \mathrm{~kg} \mathrm{~N}$ $h^{-1} a^{-1} o^{-1}$. Los cambios de vegetación y de $\mathbf{P}$ del suelo fueron mayores en distancias menores a $500 \mathrm{~m}$ de los corrales. En distancias mayores a $500 \mathrm{~m}$, los valores de vegetación y $P$ del suelo estuvieron cercanos a los esperados para pastizales de zacates cortos. El patrón de vegetación y los gradientes de fertilidad del suelo y deposición de polvo sugieren fuertemente que el corral de engorda fue la causa principal de los cambios observados, aunque no se pudo establecer una relación causal directa y otros factores, tal como el apacentamiento, pudieron haber contribuido con los cambios observados.

More than 7 million fed beef cattle, about a third of those marketed in the United States, are found within a $200,000 \mathrm{~km}^{2}$ area of this region centered on Amarillo, Tex.. Most are fed in more than 100 feedyards with capacities greater than 5000 head (Eck and Stewart 1995, SPS 2000). These concentrated feeding operations can potentially affect the local environment in many ways, 
including accumulation of manure, runoff from pens, and emissions of ammonia, dust, odors, and pathogens. In 1970, a 25,000-head feedyard was constructed and stocked adjacent to an 18.5-ha native shortgrass pasture on the USDA-ARS Conservation and Production Research Laboratory (CPRL), Bushland, Tex. After several years, scientists observed changes in the pasture's vegetation nearest the feedyard. We hypothesized that manure dust was blown from the feedyard by prevailing southwesterly winds and that this input of plant nutrients changed competitive relations between plant species, resulting in changes in vegetation composition. Our objectives were to 1) describe the historical vegetation of the pasture before the feedyard was operated; 2) quantify the composition of the current vegetation; and 3) describe changes in vegetation, soil $\mathrm{P}$ and dust deposition with distance downwind from the feedyard.

\section{Materials and Methods}

Research was conducted at the USDAARS Conservation and Production Research Laboratory, Bushland, Tex. $\left(35^{\circ} \mathrm{N}, 102^{\circ} \mathrm{W}\right.$, elevation $\left.1,170 \mathrm{~m}\right)$ in 2000 on a 13-ha portion ( $360-\mathrm{m} \times 360-\mathrm{m})$ of the 18.5-ha native shortgrass pasture. The soil was a Pullman silty clay loam (fine, mixed, thermic Torrertic Paleustoll) with slope $<1 \%$. Prevailing winds at the Conservation and Production Research Laboratory are southerly to southwesterly, with $46 \%$ of mean hourly wind directions between 157 and $248^{\circ}$. The median hourly wind speed is $4 \mathrm{~m} \mathrm{sec}^{-1}$, and $15 \%$ of mean hourly wind speeds are greater than $7 \mathrm{~m}$ $\sec ^{-1}$. Daily average wind speeds greater than $8 \mathrm{~m} \mathrm{sec}^{-1}$ are not unusual during spring months. Average annual precipitation is $476 \mathrm{~mm}, 75 \%$ of which falls from April through October. The period from October 1999 through February 2000 was dry, receiving only $31 \mathrm{~mm}$ of precipitation, compared with the historical average of $98 \mathrm{~mm}$. March precipitation was 77 $\mathrm{mm}$, almost 4 times normal. Dry weather returned from April to August, when precipitation totaled $153 \mathrm{~mm}$; the historical mean for this period is $238 \mathrm{~mm}$.

Historical vegetation was determined by archived photographs, descriptive accounts given in Whitfield et al. (1949) and measurements of a portion of the pasture reported in Eck et al. (1975). Contemporary vegetation was quantified in 600 randomly located $0.2-\mathrm{m} \times 0.5-\mathrm{m}$ quadrats. Percentage of plant canopy
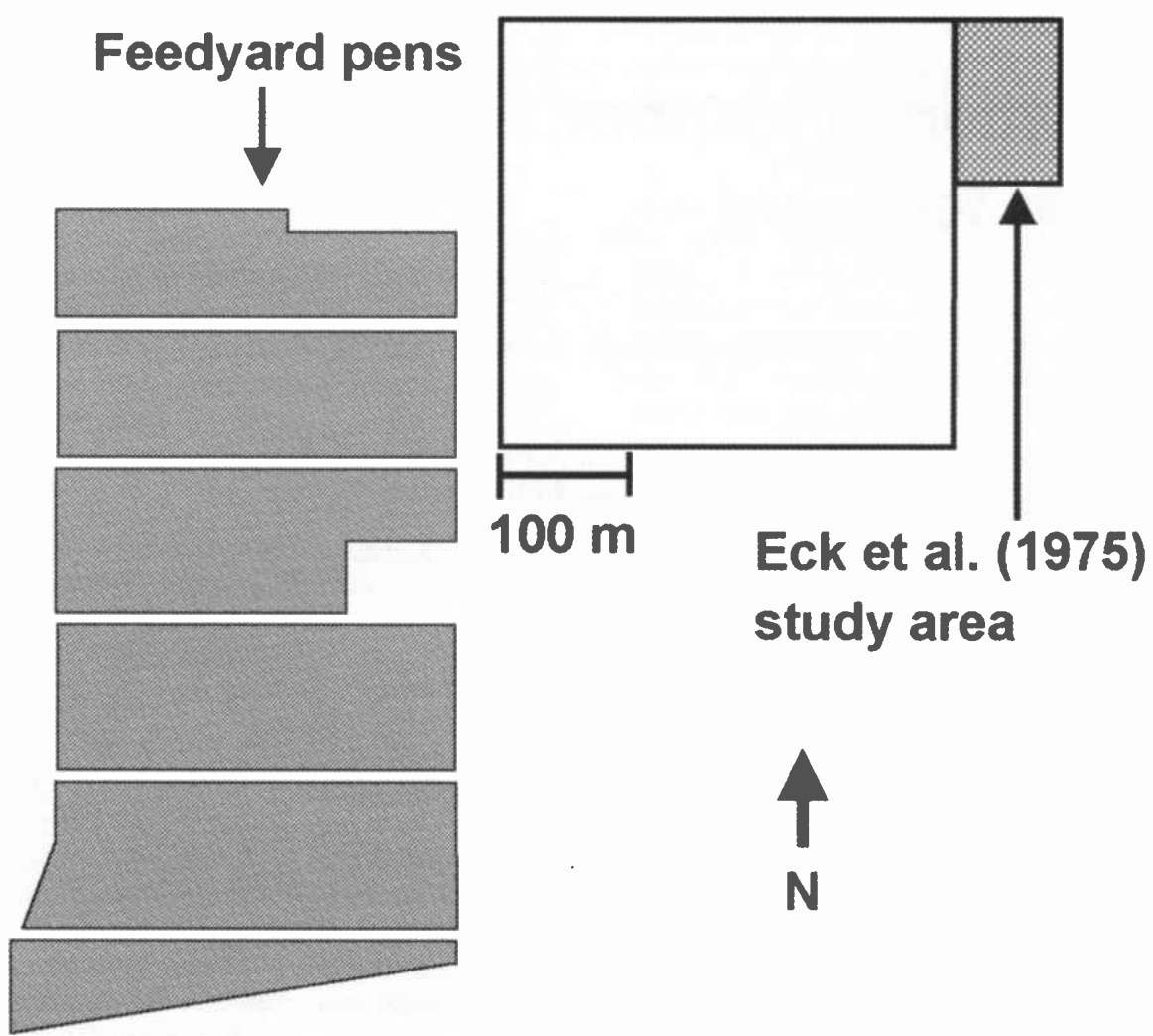

Fig 1. Study area showing the shortgrass pasture, adjacent feedyard, and the historical reference area studied by Eck et al. (1975).

cover by species was estimated using the method of Daubenmire (1959). Aboveground biomass in very fifth quadrat was clipped, for a total of 120 quadrats, and species assigned to a vegetation class: annual grass, annual forb, perennial grass, or perennial forb (Great Plains Flora Assoc. 1986). Biomass samples were airdried and mass recorded. Vegetation was sampled on 5-7 June and 21-23 Aug. 2000.

The adjacent feedyard, with a one-time capacity of 25,000 head (SPS 2000), was constructed and stocked in 1970. Feedyard pens covered about 22 ha and were located west and southwest of the native pasture (Fig. 1). The distance of each quadrat downwind from the feedyard was calculated along a southwest to northeast line, corresponding to the direction of prevailing southwesterly winds. Quadrats were then grouped into 7 distance classes by $75-\mathrm{m}$ increments (Table 1).

We used phosphorus as an indicator of manure dust additions because of its conservative nature. It is relatively immobile in manure and in Pullman soil (Smith et al. 1983, Sharpley et al. 1984, Jones et al. 1985). Soil cores were collected on 3-5 June 2000 on a $22.5-\mathrm{m} \times 30-\mathrm{m}$ grid. Greater sampling density was used on the west-to-east transects to more precisely identify the hypothesized gradient. At each sampling location, 5 cores were extracted within $1 \mathrm{~m}^{2}$ and composited by depth increment; 0 to $0.02 \mathrm{~m}, 0.02$ to 0.04 $\mathrm{m}, 0.04$ to $0.06 \mathrm{~m}, 0.06$ to $0.15 \mathrm{~m}$, and 0.15 to $0.30 \mathrm{~m}$. Soil samples were temporarily put into coolers with ice and later frozen to prevent nutrient loss. Thawed samples were air-dried, ground and passed through a 2-mm sieve, and then analyzed for Mehlich 3 (M3) extractable P (Mehlich 1984).

Dust was passively collected in 36 pans $(0.28 \times 0.23 \mathrm{~m})$ located on the pasture at 12 stations with 3 pans each. Glass marbles covered the bottoms of pans to reduce turbulence so that dust was retained. Pans

Table 1. Distance classes used to calculate cover and biomass means. Distance is distance north-east (downwind) from the feedyard.

\begin{tabular}{lccc}
\hline \hline $\begin{array}{l}\text { Distance } \\
\text { range }\end{array}$ & $\begin{array}{c}\text { Mean } \\
\text { distance }\end{array}$ & \multicolumn{2}{c}{ No. of quadrats } \\
\hline$(\mathrm{m})$ & $(\mathrm{m})$ & Cover & Biomass \\
$76-150$ & 115 & 88 & 15 \\
$151-225$ & 188 & 94 & 19 \\
$226-300$ & 260 & 80 & 18 \\
$301-375$ & 335 & 89 & 16 \\
$376-450$ & 410 & 85 & 20 \\
$451-525$ & .484 & 97 & 20 \\
$525-600$ & 552 & 67 & 12 \\
\hline
\end{tabular}


were installed on $28 \mathrm{Feb}, 2000$ and removed on 6 Mar. 2001, and the 5 collection periods varied from 43 to 104 days. Large pieces of organic matter were removed from pans before dust collection. Dust was washed from pans with distilled water into pre-weighed glass jars. Samples were air-dried and composited by position and collection period to obtain sufficient quantity for analysis. Dust samples were analyzed for M3 P.

Curves relating dependent variables to distance downwind from the feedyard were fitted with the Marquardt-Levenberg algorithm, which uses a least squares procedure to estimate parameters (Marquardt 1963).

\section{Results}

\section{Historical vegetation}

Whitfield et al. (1949) described the 18.5-ha native pasture as "dominated by blue grama and buffalograss". A photograph of the pasture taken in 1945 (Fig. 2a) reveals the typical aspect of blue grama-buffalograss steppe. Annual production of the pasture, measured in plots harvested on 1 April and 1 November from 1943 through 1948, ranged from 270 to $1,550 \mathrm{~kg} \mathrm{ha}^{-1}$ air-dry forage, and averaged $730 \mathrm{~kg} \mathrm{ha}^{-1}$. They observed that little barley (Hordeum pusillum Nutt.) significantly contributed to forage during years with wet springs that favored the cool-season annual grass. The pasture yielded $1,100 \mathrm{~kg} \mathrm{ha}^{-1}$ of little barley on 1 June 1944 following $122 \mathrm{~mm}$ of above-average precipitation received in April and May (average for the 2 months is $93 \mathrm{~mm}$ ). They also noted that little barley competed strongly for moisture and "may harm the growth of summer grasses".

A 1.4-ha area in the northeast corner of the pasture was developed into experimental plots to study runoff in 1966 (Fig. 1). Eck et al. (1975) began a study of the response of native shortgrass vegetation to time and height of clipping on the runoff plots that same year. They measured ground cover, botanical composition and dry matter yields from 1966 through 1972. Ground cover was the basal cover of vegetation measured along line transects. Vegetation cover averaged $27.6 \%$ during the study. Blue grama made up 57 to $74 \%$ of the vegetation cover and averaged $68.1 \%$ over 7 years. Blue grama had $18.8 \%$ ground cover, buffalograss had $7.4 \%$ cover, and together they comprised $95 \%$ of the vegetation cover of the plots. Forbs and other grasses were a significant
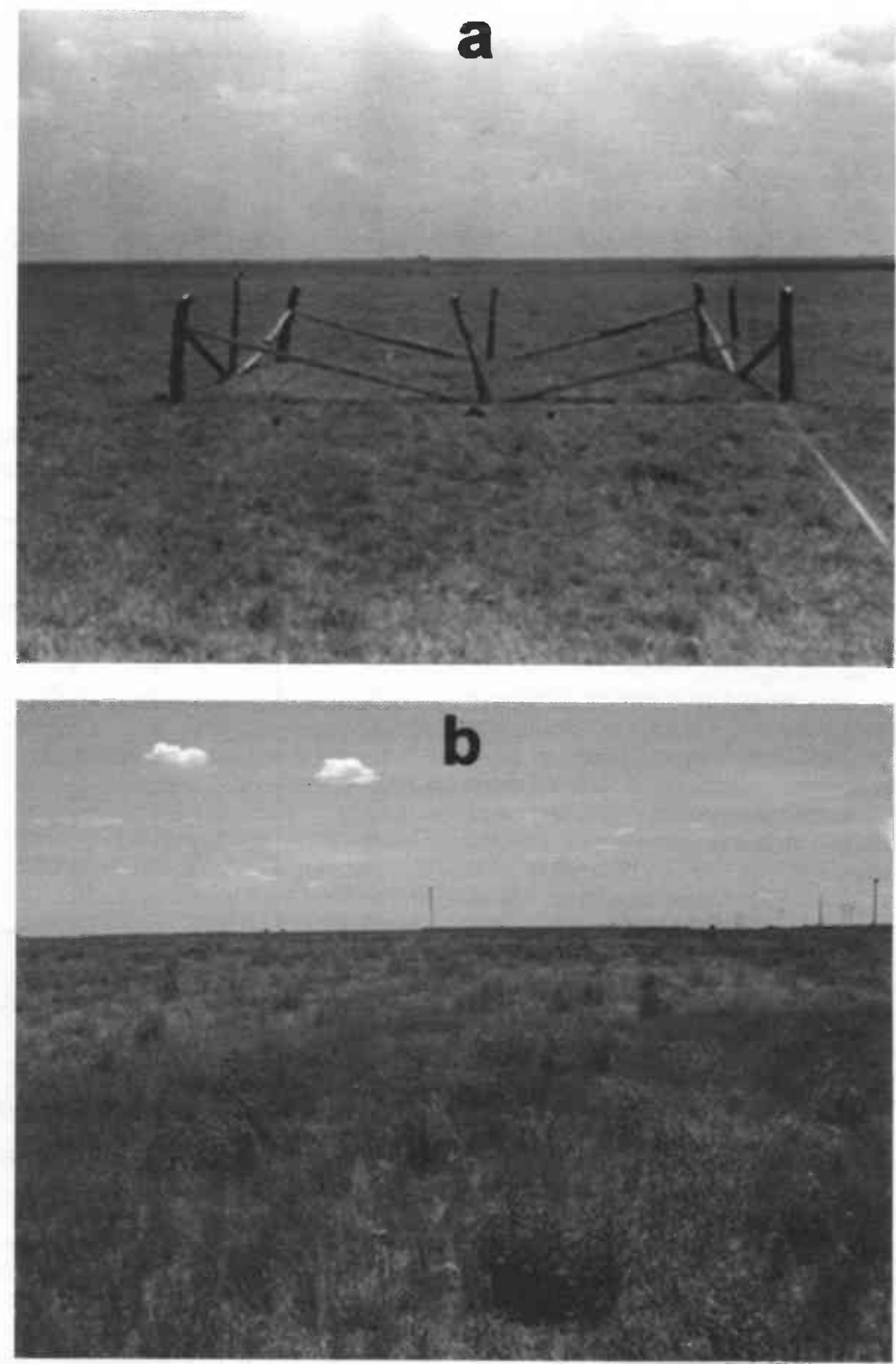

Fig 2. Photographs from near the center of the shortgrass pasture, looking south. Photograph (a) was taken on 25 June 1945; the structure is a grazing exclosure. Photograph (b) was taken on 13 July 2000; the taller, darker vegetation is kochia. The feedyard is approximately $350 \mathrm{~m}$ southwest.

component of the vegetation in 2 out of 8 years. Annual dry matter yields of plots clipped during July and October (1967 through 1970, 1972) ranged from 420 to $1,530 \mathrm{~kg} \mathrm{ha}^{-1}$ and averaged $1,240 \mathrm{~kg} \mathrm{ha}^{-1}$.

Vegetation west of the runoff plots was not measured by Eck et al. (1975). However the range of annual production was similar for the pasture during the 1940 s and the runoff plots during the 1970s. Visual observations by scientists support the uniformity of the pasture's vegetation in the 1960 s. Uniformity of shortgrass prairie dominated by blue grama and buffalograss over an extensive area is typical where topography and soil vary little, as in this case. The vegetation of the pasture also showed temporal uniformity for 29 years between 1943 and 1972. Studies on the runoff plots in 1976 to 1980 (Smith et al. 1983), 1978 to 1983 (Jones et al. 1985), and 1993 to 1994 
(Willis 1995) also characterized the vegetation there as predominantly blue grama and buffalograss. We assumed that the plant composition reported by Eck et al. (1975) for the runoff plots represented the entire pasture, and reflected the historical vegetation prior to construction and operation of the feedyard.

\section{Contemporary vegetation}

The photograph in Fig. $2 \mathrm{~b}$ was taken on 13 July 2000 from the middle of the pasture looking south, at approximately the same position and direction as the 25 June 1945 photograph in Fig. 2a. The darker vegetation was kochia [Kochia scoparia (L.) Schrad.], which comprised about $48 \%$ of the vegetation cover in the near field of the photograph. Blue grama comprised about $36 \%$ of the vegetation cover. This contrasts with the absence of forbs in the photograph in Fig. 2a, in the grazed foreground and in the exclosure.

Annual grass [little barley, Japanese brome (Bromus japonicus Thunb. ex Murr.) and downy brome (Bromus tectorum L.)] cover sampled in June averaged 49\% nearest the feedyard and decreased linearly with distance downwind from the feedyard $\left(C=57.0-0.09 \mathrm{D}, \mathrm{r}^{2}=0.94\right.$, RMSE $=2.9)$ to $9 \%$ at more than $525 \mathrm{~m}$ (Fig. 3a). Cool-season annual grasses were dead and not tallied in August, and only a trace of annual grass cover was contributed by witchgrass (Panicum capillare L). Annual forb [mostly kochia, redroot pigweed (Amaranthus retroflexus L.), and smooth pigweed (Amaranthus hybridus L.)] cover also decreased linearly with distance from the feedyard in June $(C=9.18$ - 0.0145 D, $\mathrm{r}^{2}=0.79$, RMSE $\left.=1.0\right)$ and August $\left(C=37.92-0.0677 \mathrm{D}, \mathrm{r}^{2}=0.91\right.$, RMSE $=3.1$ ), from 8 and 35\%, respectively, nearest the feedyard, to $<1 \%$ at more than $525 \mathrm{~m}$ (Fig. 3b).

Perennial grass (blue grama, buffalograss, western wheatgrass [Pascopyrum smithii Rydb.], and sand dropseed [Sporobolus cryptandrus (Torr.) A. Gray]) cover increased exponentially with distance downwind from the feedyard in June $\left[C=1.26 \exp (0.0052 \mathrm{D}), \mathrm{r}^{2}=0.99, \mathrm{RMSE}\right.$ $=0.79]$ and August $[C=1.60 \exp (0.0052$ D), $r^{2}=0.99$, RMSE $=0.71$ ] (Fig. 4a). In June, perennial grass cover averaged $1.5 \%$ in quadrats less than $150 \mathrm{~m}$ from the feedyard and increased to $22.4 \%$ at distance greater than $525 \mathrm{~m}$. Perennial grass cover in August ranged from $4.2 \%$ closest to the feedyard to $29.2 \%$ at distance downwind from the feedyard greater than $525 \mathrm{~m}$. Perennial forb cover was variable in distribution and showed no directional pattern,
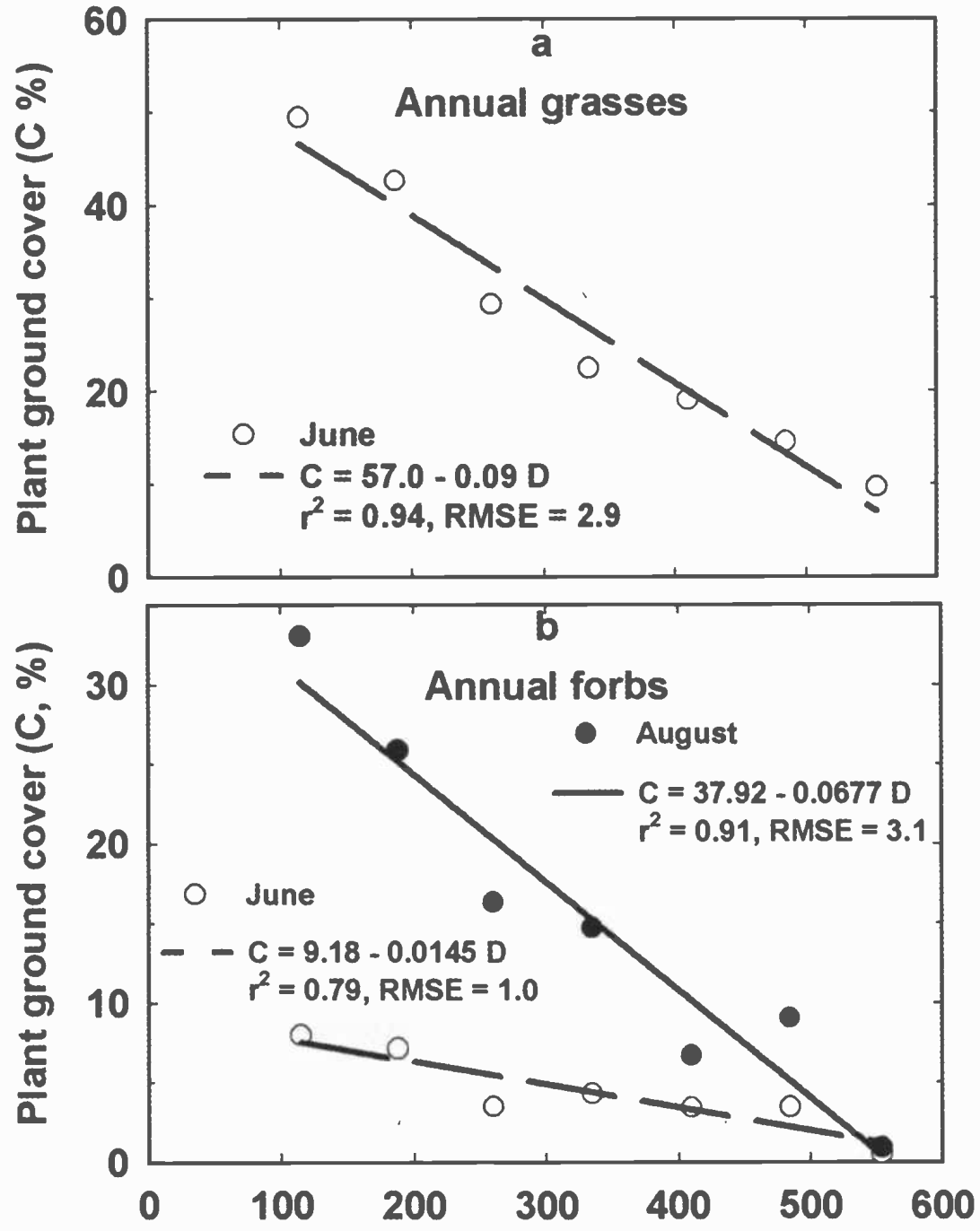

\section{Distance downwind (NE) from feedyard (D, $m$ )}

Fig 3. Ground cover (C, \%) of annual grasses (a) and annual forbs (b) with distance (D, $m$ ) downwind from the feedyard.

except for a near-absence of perennial forbs in quadrats less than $150 \mathrm{~m}$ from the feedyard (Fig. 4b).

Little barley was the dominant annual grass (Table 2). It was ubiquitous, occurring in the pasture with a frequency of $90 \%$. Japanese brome cover was greatest between 300 and $450 \mathrm{~m}$ from the feedyard. Kochia and pigweed dominated areas closest to the feedyard during the summer. Kochia cover in August was almost 33 times greater in quadrats less than $150 \mathrm{~m}$ from the feedyard, compared with those more than $525 \mathrm{~m}$ distant. Pigweed cover was more than 112 times greater in the closest quadrats, compared with those farthest from the feedyard. Pigweed cover in August was underestimated because pigweed was waterstressed and dropped many leaves during a dry period prior to sampling.
Blue grama comprised from 75 to $99 \%$ of perennial grass cover, and its cover increased more than 13-fold with distance from the feedyard in June, and almost 10fold in August (Table 2). Blue grama cover more than $450 \mathrm{~m}$ from the feedyard (16.7\% in June and $21.5 \%$ in August) was similar to the $18.8 \%$ average basal cover measured from 1966 to 1972 by Eck et al. (1975) using a line transect method. Our estimate of blue grama and buffalograss cover included the living basal area and taller foliage. However, the taller foliage contributed only a small fraction of the total ground cover because it usually overlapped the basal clump. Blue grama contributed 50\% and $70 \%$ (June and August, respectively) of the total vegetation cover more than $450 \mathrm{~m}$ from the feedyard, compared with $68 \%$ reported by Eck et al. (1975). Buffalograss was absent or 
Table 2. Average canopy cover $(\%)$ with distance from feedyard, by major species. Mean is followed by standard deviation in parentheses.

\begin{tabular}{|c|c|c|c|c|c|c|c|}
\hline $\begin{array}{l}\text { Mean } \\
\text { Distance }\end{array}$ & Little barley & Japanese brome & Kochia & Pigweed & Blue grama & Buffalograss & $\begin{array}{c}\text { Silverleaf } \\
\text { nightshade }\end{array}$ \\
\hline \multirow{2}{*}{\multicolumn{8}{|c|}{ June }} \\
\hline & & & & & & & \\
\hline 115 & $46.6(26.5)$ & $0.2(1.6)$ & $4.2(10.0)$ & $2.4(10.1)$ & $1.6(4.4)$ & 0 & $\mathrm{t}$ race \\
\hline 188 & $37.4(21.1)$ & $4.4(10.6)$ & $4.9(11.5)$ & $0.7(2.2)$ & $3.9(7.5)$ & 0 & $2.2(5.0)$ \\
\hline 260 & $21.3(18.2)$ & $4.3(10.0)$ & $2.3(4.1)$ & $0.5(1.8)$ & $4.5(7.0)$ & $0.2(1.7)$ & $2.3(4.9)$ \\
\hline 335 & $5.7(6.3)$ & $14.0(17.6)$ & $3.5(8.5)$ & $0.3(0.7)$ & $6.3(10.4)$ & $0.1(0.7)$ & $2.4(5.1)$ \\
\hline 410 & $9.6(9.3)$ & $9.7(14.1)$ & $1.6(3.2)$ & $0.1(0.3)$ & $9.2(11.1)$ & $0.4(1.8)$ & $0.3(1.7)$ \\
\hline 484 & $10.1(9.1)$ & $4.0(6.4)$ & $1.3(6.7)$ & $0.1(0.3)$ & $13.3(15.2)$ & $0.3(1.6)$ & $0.2(1.5)$ \\
\hline 552 & $7.0(8.1)$ & $2.4(3.8)$ & $0.1(0.4)$ & trace & $21.6(20.4)$ & $0.7(2.7)$ & $0.2(0.07)$ \\
\hline \multicolumn{8}{|l|}{ August } \\
\hline 115 & - & - & $23.2(30.6)$ & $11.2(15.8)$ & $2.8(8.4)$ & 0 & $0.2(1.6)$ \\
\hline 188 & - & - & $22.4(28.8)$ & $2.1(5.4)$ & $4.2(9.2)$ & 0 & $3.3(8.0)$ \\
\hline 260 & - & - & $13.7(20.2)$ & $1.0(2.5)$ & $6.4(11.7)$ & 0 & $1.5(4.0)$ \\
\hline 335 & - & - & $12.2(16.0)$ & $0.4(0.8)$ & $9.1(12.7)$ & 0 & $1.6(6.2)$ \\
\hline 410 & - & - & $4.2(7.4)$ & $1.0(2.5)$ & $13.1(13.7)$ & 0 & $1.3(4.1)$ \\
\hline 484 & - & - & $3.1(6.1)$ & $1.4(3.8)$ & $17.2(14.9)$ & $0.2(1.5)$ & $1.3(5.2)$ \\
\hline 552 & - & - & $0.7(2.6)$ & $0.1(0.3)$ & $27.8(19.5)$ & $0.4(2.0)$ & $0.8(3.2)$ \\
\hline
\end{tabular}

uncommon and comprised from 0 to less than $2 \%$ of the total vegetation cover, compared with $27 \%$ of the total vegetation cover reported by Eck et al. (1975). Buffalograss and blue grama are readily distinguished to the trained eye, and the absence of buffalograss in several distance classes is attributed to its actual rarity. Silverleaf nightshade (Solanum elaeagnifolium Cav.) was the major perennial forb. It comprised more than $88 \%$ of the perennial forb cover within $300 \mathrm{~m}$ of the feedyard, but its contribution decreased to $34 \%$ at more than $525 \mathrm{~m}$. Total vegetation cover closest to the feedyard was $58 \%$ in June, due largely to little barley, and $39 \%$ in August. In quadrats farthest from the feedyard, total vegetation cover averaged $34 \%$ and $32 \%$ (June and August, respectively), about $20 \%$ greater than the 6 -year mean of $27.6 \%$ reported by Eck et al. (1975).

Annual grass and annual forb biomass were greatest at less than $375 \mathrm{~m}$, and then decreased with distance from the feedyard (Table 3). Annual forb biomass averaged $4670 \mathrm{~kg} \mathrm{ha}^{-1}$ at less than $225 \mathrm{~m}$. Annual grass biomass was more than $1400 \mathrm{~kg} \mathrm{ha}^{-1}$ as far away as $375 \mathrm{~m}$ because of biomass contributed by downy and Japanese brome distributed near the center of the pasture. Perennial grass biomass increased with distance from the feedyard from $11 \mathrm{~kg} \mathrm{ha}^{-1}$ to more than $800 \mathrm{~kg} \mathrm{ha}^{-1}$. Total biomass nearest the feedyard was almost 5 times the total biomass measured at more than $500 \mathrm{~m}$.

Annual grasses were a significant fraction of the total biomass of all distance classes, ranging from 19 to $52 \%$ (Fig. 5). The fraction of total biomass contributed by annual forbs decreased linearly with distance from the feedyard from more than
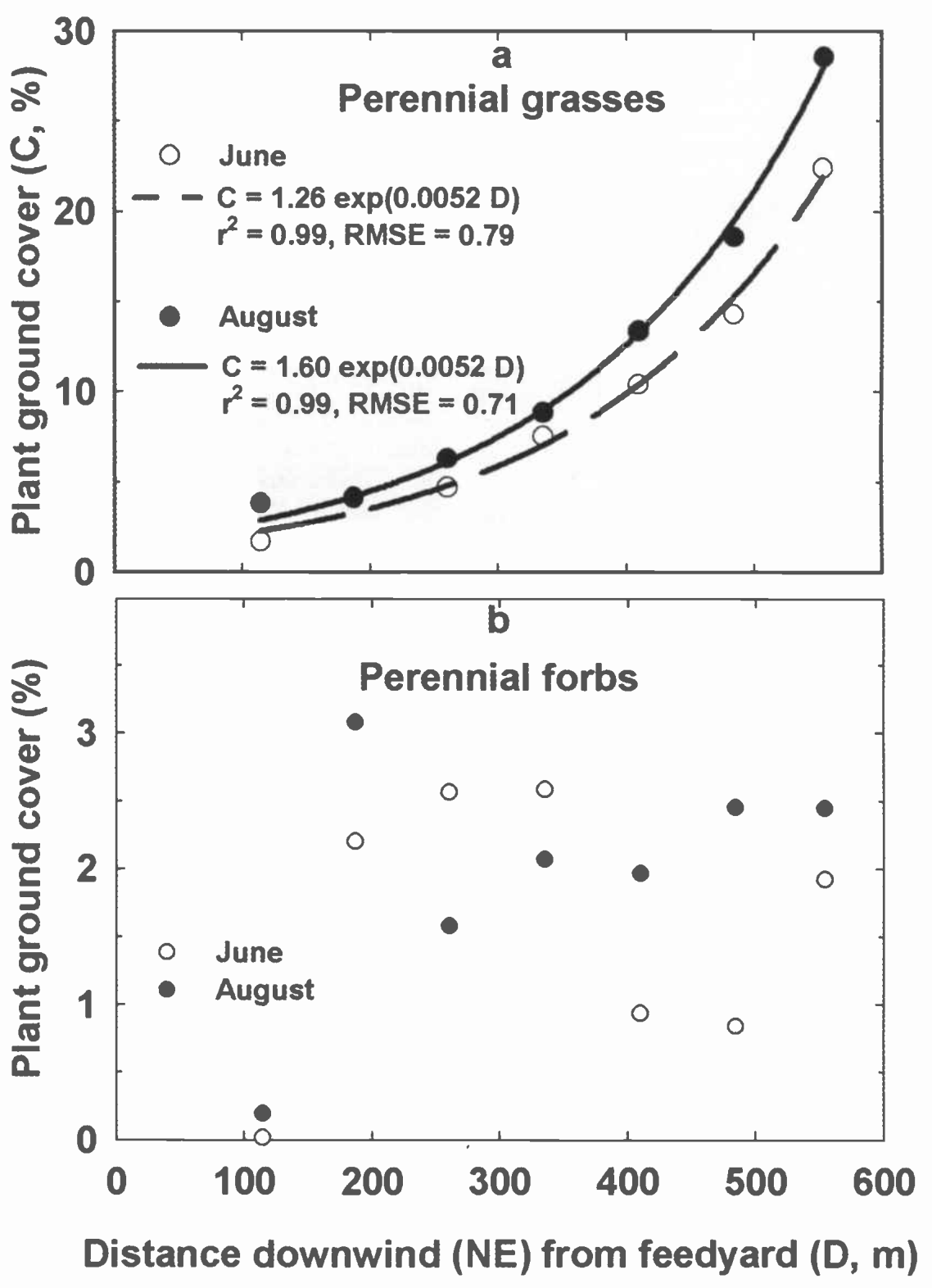

Fig 4. Ground cover (C, \%) of perennial grasses (a) and perennial forbs (b) with distance (D, m) downwind from the feedyard. 
Table 3. Plant air-dry biomass $\left(\mathrm{kg} \mathrm{ha}^{-1}\right)$ with distance from the feedyard, by vegetation class. Annual grasses were sampled in June, 2000, other vegetation classes in August, 2000. Mean is followed by standard deviation in parentheses.

\begin{tabular}{lccccc}
\hline \hline $\begin{array}{l}\text { Mean } \\
\text { Distance }\end{array}$ & $\begin{array}{c}\text { Annual } \\
\text { grasses }\end{array}$ & $\begin{array}{c}\text { Annual } \\
\text { forbs }\end{array}$ & $\begin{array}{c}\text { Perennial } \\
\text { grasses }\end{array}$ & $\begin{array}{c}\text { Perennial } \\
\text { forbs }\end{array}$ & Total \\
\hline$(\mathrm{m})$ & & & & & \\
115 & $1070(680)$ & $4660(3240)$ & $11(44)$ & $22(65)$ & 5760 \\
188 & $1640(850)$ & $4680(5890)$ & $240(440)$ & $280(1060)$ & 6840 \\
260 & $1540(660)$ & $740(730)$ & $220(380)$ & $460(760)$ & 2960 \\
335 & $1430(1050)$ & $1370(2650)$ & $500(690)$ & $340(770)$ & 3630 \\
410 & $600(290)$ & $620(860)$ & $510(580)$ & $440(1030)$ & 2170 \\
484 & $520(210)$ & $120(200)$ & $830(480)$ & $300(650)$ & 1770 \\
552 & $440(230)$ & $8(20)$ & $800(570)$ & $44(93)$ & 1290 \\
\hline
\end{tabular}

Table 4. Regression coefficients and statistics for the change of dust deposition rate $\left(R, \mathrm{~g} \mathrm{~m}^{-2} \mathrm{day}^{-1}\right)$ with distance $(D, m)$ downwind from the feedyard, fitted to $R=a \exp (b \mathrm{D})$.

\begin{tabular}{lcccccc}
\hline \hline Collection Period & Begin Date & \# Days & $\mathrm{a}$ & $\mathrm{b}$ & $\mathrm{r}^{2}$ & RMSE \\
\hline Spring (sp) & 12 Apr. & 43 & 1.17 & -0.0036 & 0.78 & 0.24 \\
Early summer (es) & 31 May & 48 & 4.78 & -0.0044 & 0.87 & 0.49 \\
Late summer (ls) & 17 Jul. & 62 & 3.61 & -0.0048 & 0.93 & 0.27 \\
Fall (f) & 17 Sep. & 66 & 1.78 & -0.0045 & 0.82 & 0.25 \\
Winter (w) & 23 Nov. & 104 & 0.40 & -0.0026 & 0.57 & 0.08 \\
\hline
\end{tabular}

$80 \%$ to less than $1 \%$. The contribution of perennial grasses to total biomass increased exponentially with distance from the feedyard from less than $1 \%$ to $62 \%$. Total biomass less than $450 \mathrm{~m}$ from the feedyard, composed mostly of annual grasses and annual forbs, was from 1.4 to 4.4 times greater than the maximum biomass yields reported by Whitfield et al. (1949) and Eck et al. (1975). Biomass yields at greater distances were near the upper range of yields (1530-1550 $\mathrm{kg} \mathrm{ha}^{-1}$ ) reported in the earlier studies.

\section{Soil Phosphorus}

Mehlich 3 extractable $P$ concentration of Pullman soil is typically around $15 \mathrm{mg} \mathrm{kg}^{-1}$ in surface horizons of undisturbed shortgrass prairie (R.C. Schwartz, pers. comm. 2003). We measured 5 times that concentration in the top $0.3 \mathrm{~m}$ of soil in sample cores less than $150 \mathrm{~m}$ downwind from the feedyard, with M3 P concentration ranging as high as $186 \mathrm{mg} \mathrm{kg}^{-1}$. Phosphorus decreased exponentially with distance downwind from the feedyard $[\mathrm{P}=95.9$ $\left.\exp (-0.0032 \mathrm{D}), \mathrm{r}^{2}=0.88, \mathrm{RMSE}=5.6\right]$ to levels within the typical range at more than $525 \mathrm{~m}$ from the feedyard (Fig. 6).

\section{Dust Deposition and Dust $P$ \\ Concentration}

Dust deposition rate during the 5 collection periods decreased exponentially with distance downwind from the feedyard (Fig. 7; regression coefficients and statistics given in Table 4). Deposition rate at $117 \mathrm{~m}$ from the feedyard was greatest durannualized dust deposition rate of $2.4 \mathrm{Mg}$ $\mathrm{ha}^{-1}$ year ${ }^{-1}$. August 2000.
Dust can be composed of soil, or pulverized manure or road surface. Local soil typically contains less than $20 \mathrm{mg} \mathrm{kg}^{-1} \mathrm{M} 3$ $\mathrm{P}$, and caliche (mostly $\mathrm{CaCO}_{3}$ ) used to surface roads has negligible $\mathrm{P}$. Feedyard manure, however, contains about $4800 \mathrm{mg}$ $\mathrm{kg}^{-1} \mathrm{M} 3 \mathrm{P}$, so that its concentration in dust can be used as an indicator of manure dust. Mehlich $3 \mathrm{P}$ concentrations were greatest during early summer, when dust was estimated to be from 67 to $89 \%$ manure (Table 5). Lowest measurable $P$ concentrations were during the fall, when the fraction of manure in dust ranged from 1 to $20 \%$ across the pasture. Winter dust contained no measurable P. Weighted average M3 $P$ concentration of dust samples across the pasture was $1,370 \mathrm{mg} \mathrm{kg}^{-1}$, giving a manure dust fraction of about $29 \%$.

\section{Nutrient Additions to Pasture}

Nutrient loading to the pasture can be estimated in 2 ways. First, we estimated annual manure dust deposition using the total dust deposition rate and dust $\mathrm{P}$ concentration. Second, we calculated how much manure dust deposition was needed to increase soil M3 P in the top $0.3 \mathrm{~m}$ from an undisturbed concentration $\left(15 \mathrm{mg} \mathrm{kg}^{-1}\right)$ to the observed concentration. In laboratory studies at Bushland (R.C. Schwartz, pers. comm. 2002), $2.8 \mathrm{~kg} \mathrm{ha}^{-1}$ of total $P$ was needed to increase M3 P in Pullman soil by $1 \mathrm{mg} \mathrm{kg}^{-1}$, and this relationship was

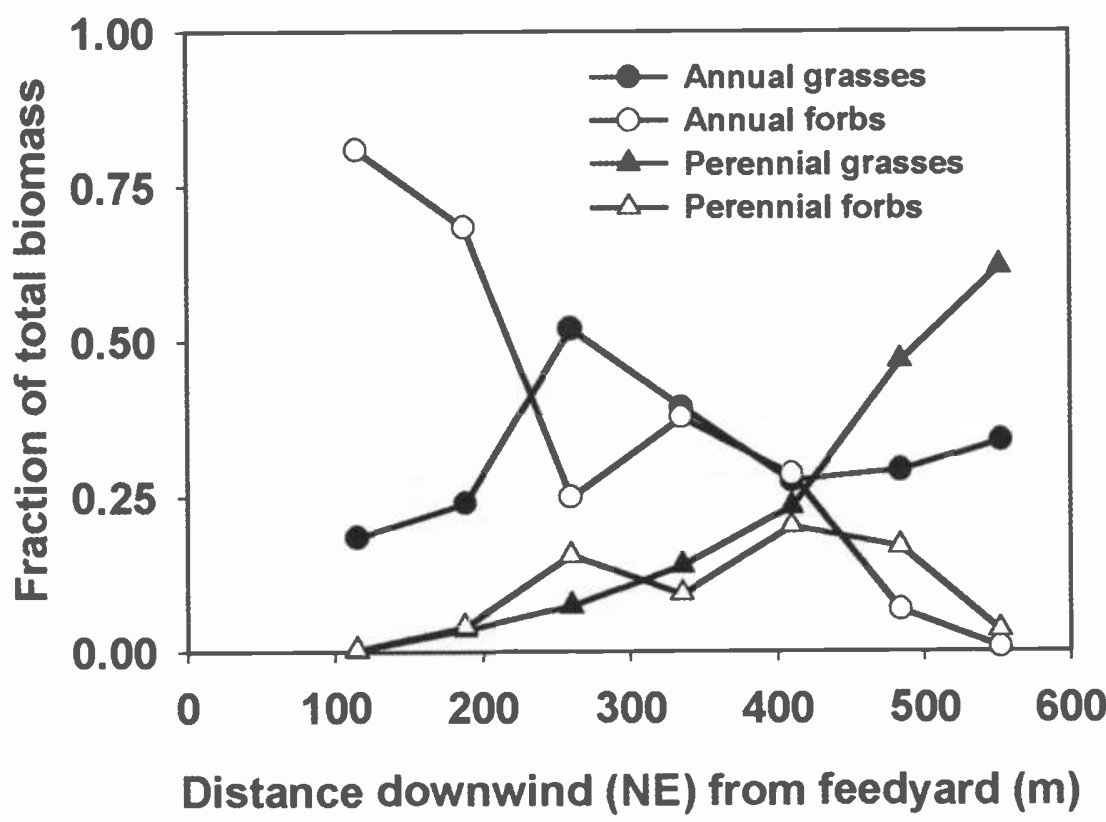

Fig. 5. Fraction of total biomass contributed by vegetation classes with distance downwind from the feedyard. Annual grasses were sampled in June 2000, other vegetation classes in 
Table 5. Mean Mehlich 3 extractable phosphorus concentration ( $\mathrm{mg} \mathrm{P}^{-.1}$ ) in dust. Number in parentheses is the standard deviation of the mean of 3 locations at a given distance. All dates are in 2000, except Winter, which spanned 2000-2001. Mean for a distance class is weighted by number of days in each collection period.

\begin{tabular}{|c|c|c|c|c|c|c|}
\hline $\begin{array}{l}\text { Mean } \\
\text { distance }\end{array}$ & $\begin{array}{c}\text { Spring } \\
\text { (12 Apr. - 31 May) }\end{array}$ & $\begin{array}{c}\text { Early summer } \\
\text { (31 May - } 17 \text { Jul.) }\end{array}$ & $\begin{array}{c}\text { Late summer } \\
\text { (17 Jul. - } 17 \text { Sep.) }\end{array}$ & $\begin{array}{c}\text { Fall } \\
\text { (17 Sep. }-23 \text { Nov.) }\end{array}$ & $\begin{array}{c}\text { Winter } \\
\text { (23 Nov. - } 6 \text { Mar.) }\end{array}$ & Weighted \\
\hline \multicolumn{7}{|l|}{ (m) } \\
\hline 117 & $1200(180)$ & $4220(560)$ & $2280(600)$ & $950(270)$ & 0 & 1420 \\
\hline 258 & $1520(520)$ & $4280(480)$ & $3150(2280)$ & $950(290)$ & 0 & 1640 \\
\hline 400 & $1670 \ddagger$ & $3810(610)$ & $3740(900)$ & $210(170)$ & 0 & 1550 \\
\hline 541 & $1520 \ddagger$ & $3220 \ddagger$ & $1040 \dagger$ & $60 \ddagger$ & 0 & 890 \\
\hline
\end{tabular}

$\doteqdot$ One location with enough dust for analysis.

$\ddagger$ Mean of 2 locations with enough dust for analysis.

used to convert between M3 P and total P. Manure total $\mathrm{N}$ and total $\mathrm{P}$ concentrations were assumed to be $2 \%$ and $0.6 \%$, respectively, based on our experience with manure composition. Mean annual manure dust deposition to the entire pasture was $710 \mathrm{~kg} \mathrm{ha}^{-1}$ year $^{-1}$ based on dust measurements, and $330 \mathrm{~kg} \mathrm{ha}^{-1}$ year-1 based on increase in soil P. Nitrogen loading to the pasture decreased with distance from the feedyard, ranging from 31 to $3 \mathrm{~kg} \mathrm{ha}^{-1}$ year $^{-1}$ with estimates based on dust, and from 19 to $<1 \mathrm{~kg} \mathrm{ha}^{-1}$ year $^{-1}$ when based on soil $\mathrm{P}$ increases (Fig. 8).

\section{Discussion}

Increase in annual grasses and forbs and decrease in perennial grasses that we observed in the pasture closest to the feedyard were consistent with changes measured when High Plains rangeland was fertilized with inorganic nitrogen. Studies on the northern High Plains (Rauzi 1978, 1979, Rauzi and Fairbourn 1983, Samuel and Hart 1998, Paschke et al. 2000) showed that $\mathrm{N}$ fertilization of short and mixed grass rangeland at rates ranging from 22 to $672 \mathrm{~kg} \mathrm{~N}^{-1}$ changed plant composition and productivity. Cool-season grasses and annual forbs responded positively to nitrogen, and annual forbs became a major component of vegetation. Blue grama responded variably; biomass increased short-term, but frequency and contribution to total biomass decreased long-term. Buffalograss was dramatically reduced to a minor component of the vegetation, as we observed in this study. Nitrogen applied at one-time rates of 0 , 56,112 , and $224 \mathrm{~kg} \mathrm{~N}^{-1}$ increased dry matter yield of western wheatgrass and other cool-season grasses in monoculture by up to $127 \%$ in Montana (Jacobsen et al. 1996). Competitive effects between $\mathrm{N}$ -

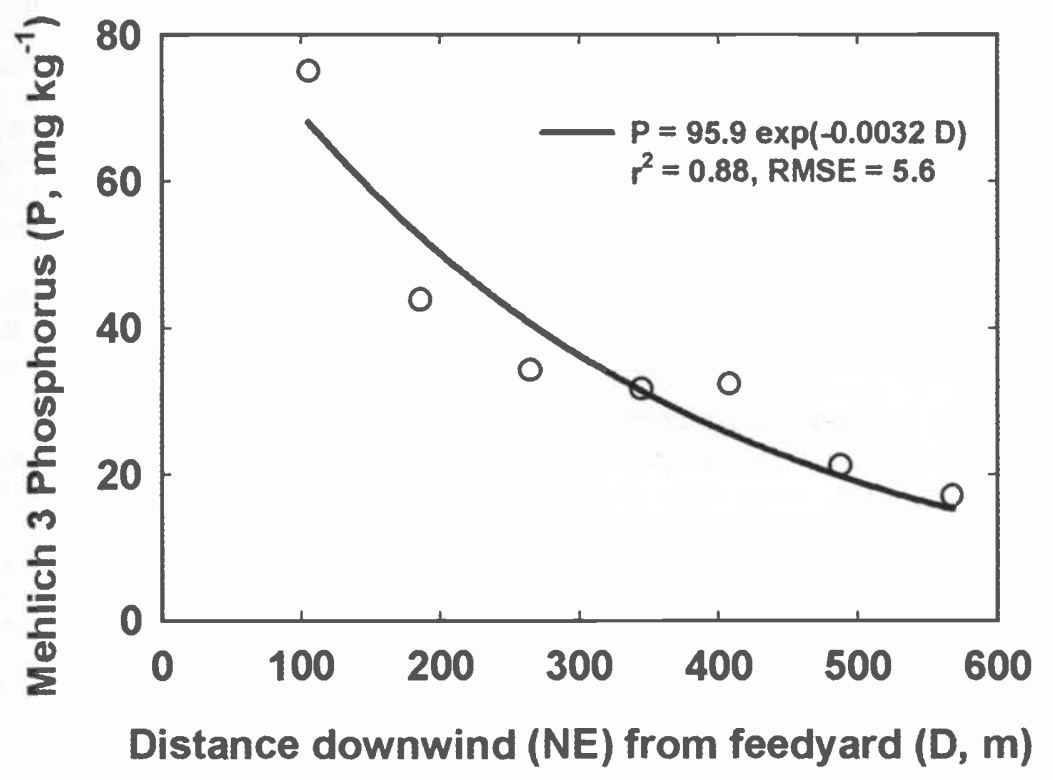

Fig. 6. Mehlich 3 extractable phosphorus concentration $\left(P, \mathrm{mg} \mathrm{kg}^{-1}\right)$ in the top $0.3 \mathrm{~m}$ of soil with distance $(D, m)$ downwind from the feedyard. and P-fertilized blue grama and buffalograss were observed by Richard and Redente (1995). Blue grama was more competitive than buffalograss, especially when nutrients were highly available.

Estimates of nitrogen loading to the pasture indicated that $20-30 \mathrm{~kg} \mathrm{~N}^{-1}$ could have been added annually by dust to areas closest to the feedyard where the most dramatic changes in soil fertility and vegetation occurred. Nitrogen additions of this magnitude over 30 years could easily have induced vegetation changes, given the sensitivity of shortgrass prairie to increased soil fertility. Feedyards can also be significant sources of ammonia (Hutchinson et al. 1982), which can be taken up by plants. Smith et al. (1983), working on the runoff plots in the northeast corner of the pasture, found greater ammonium concentration in water collected from the runoff plots compared with other southern Great Plains grasslands and attributed it "to ammonia drift from a nearby cattle feedyard", though they presented no evidence to support the conjecture.

As vegetation changed in response to increased soil fertility, a complex of interrelated factors could also have contributed to the degradation of the pasture, including differences in soil water availability caused by changes in vegetation composition and seasonality, and preferential use and grazing of the west side of the pasture by cattle. For example, evapotranspiration rates of a cool-season grass during the winter measured by Howell et al. (1998) often ranged from 1 to $3 \mathrm{~mm}^{\text {day }}{ }^{-1}$. If we assume, conservatively, that evapotranspiration averages $2 \mathrm{~mm}^{\text {day }^{-1}}$ for 90 days during the spring, then total spring water use is $180 \mathrm{~mm}$. Long-term meteorological records at CPRL show that Novemberthrough-May precipitation was less than $180 \mathrm{~mm}$ in 17 out of 30 years. Vigorous early spring growth of annual grasses and forbs could have used up available water during most years, so that when blue grama initiated growth in late spring, 


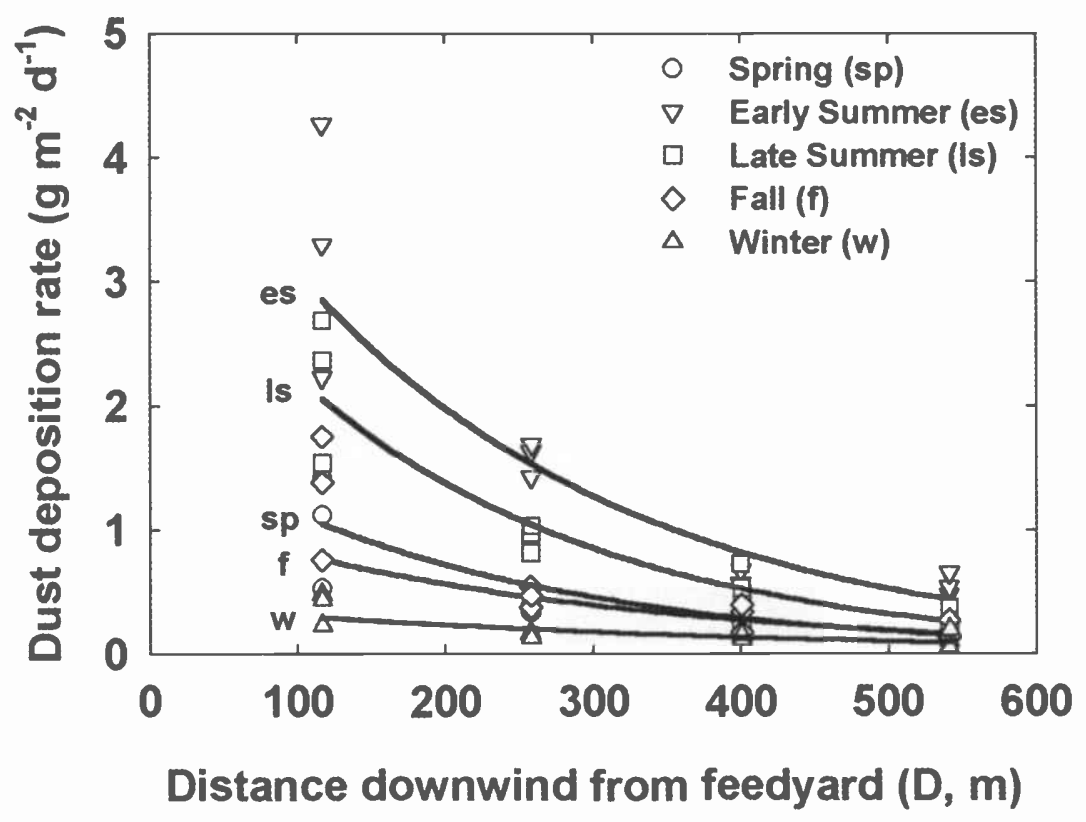

Fig. 7. Seasonal dust deposition rate $\left(R, g^{-2} d^{-1}\right)$ with distance $(D, m)$ downwind from the feedyard.

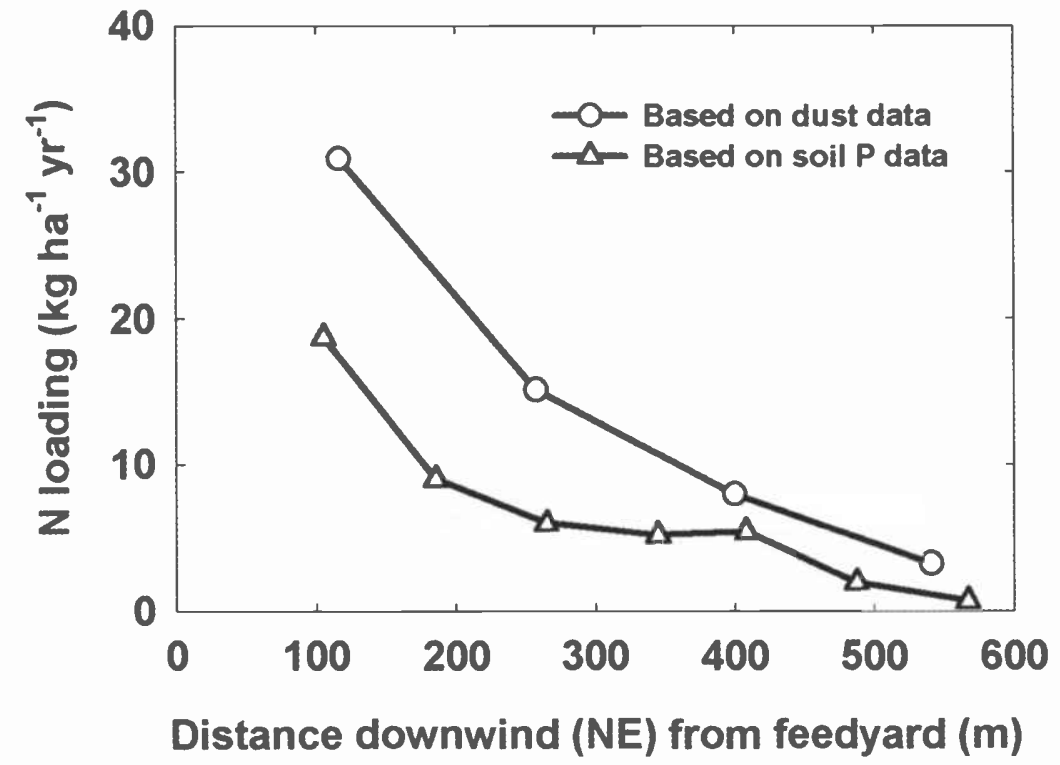

Fig. 8. Estimated annual nitrogen loading to shortgrass prairie pasture with distance downwind from the feedyard.

available soil water was reduced or depleted. Whitfield et al. (1949) observation that little barley could strongly compete for water and possibly harm warm-season grasses was perceptive.

We were not able to assess the effect of cattle grazing on vegetation and soil changes. Cattle lightly to moderately grazed the pasture during part of most years or were absent. Comparable changes were not observed in other pastures similarly managed, but more distant from the feedyard. Although the impact of cattle use is uncertain, preferential use of the west half of the pasture may have helped to further shift vegetation composition after initial changes induced by increased fertility.

\section{Conclusions}

The pattern of vegetation, soil fertility, and dust deposition spatial gradients observed in a shortgrass pasture downwind from a beef cattle feedyard strongly suggested that manure dust blown from the feedyard and subsequent changes in soil fertility were the primary cause of the changes that occurred over 30 years after the feedyard began to operate. However, we weren't able to establish the direct causal impact of the feedyard nor assess a level of certainty. We were also not able to assess the impact of other possible causes of vegetation and soil fertility change, such as grazing. Although the pasture degraded severely nearest the feedyard, changes were limited to areas less than $500 \mathrm{~m}$ downwind.

\section{Literature Cited}

Daubenmire, R. 1959. A canopy coverage method of vegetational analysis. N.W. Sci. 33:43-64.

Eck H.V. and B.A. Stewart. 1995. Manure, p. 169-198. In: J.R. Rechcigl (ed.) Soil amendments and environmental quality. Lewis Pub., Boca Raton, Fla.

Eck, H.V., W.G. McCully, and J. Stubbendick. 1975. Response of shortgrass plains vegetation to clipping, precipitation, and soil water. J. Range Manage. 28:194-197.

Great Plains Flora Assoc. 1986. Flora of the Great Plains. McGregor, R.L., T.M. Barkley, R.E. Brooks, and E.K. Schofield (eds.) University Press of Kansas, Lawrence, Kans.

Howell, T.A., S.R. Evett, A.D. Schneider, R.W. Todd, and J.A. Tolk. 1998. Evapotranspiration of irrigated fescue grass in a semi-arid environment. 1998 Annual Internat. Meeting of the Amer. Soc. of Agr. Engin., Paper No. 982119. Amer. Soc. Agr. Eng., Joseph, Mich.

Hutchinson, G.L., A.R. Mosier, and C.E. Andre. 1982. Ammonia and amine emissions from a large cattle feedlot. J. Environ. Qual. 11:288-293.

Jacobsen, J.S., S.H. Lorbeer, H.A.R. Houlton, and G.R. Carlson. 1996. Nitrogen fertilization of dryland grasses in the northern Great Plains. J. Range Manage. 49:340-345.

Jones, O.R., H.V. Eck, S.J. Smith, G.A. Coleman, and V.L. Hauser. 1985. Runoff, soil, and nutrient losses from rangeland and dry-farmed cropland in the southern High Plains. J. Soil Wat. Cons. 40:161-164.

Marquardt, D.W. 1963. An algorithm for least squares estimation of parameters. J. Soc. Industrial and Appl. Math. 11:431-441.

Mehlich, A. 1984. Mehlich 3 soil test extractant: a modification of Mehlich 2 extractant. Communications in Soil Science and Plant Analysis. 15:1409-1416.

Paschke, M.W., T. McLendon, and E.F. Redente. 2000. Nitrogen availability and old-field succession in a shortgrass steppe. Ecosystems 6:144-158.

Rauzi, F. 1978. High rates of nitrogen change composition of shortgrass rangeland in 
southeastern Wyoming. J. Range Manage. 31:366-370.

Rauzi, F. 1979. Residual effect of phosphorus and high rates of nitrogen on shortgrass rangeland. J. Range Manage. 32:470-474.

Rauzi, F. and M.L. Fairbourn. 1983. Effects of annual applications of low $\mathrm{N}$ fertilizer rates on a mixed grass prairie. J. Range Manage. 36:359-362.

Richard, C.E. and E.F. Redente. 1995. Nitrogen and phosphorus effects on blue grama and buffalograss interactions. J. Range Manage. 48:417-422.
Samuel, M.J. and R.H. Hart. 1998. Nitrogen fertilization, botanical composition and biomass production on mixed-grass rangeland. J. Range Manage. 51:408-416.

Sharpley, A.N., S.J. Smith, B.A. Stewart, and A.C. Mathers. 1984. Forms of phosphorus in soil receiving cattle feedlot waste. J. Environ. Qual. 13:211-215.

Smith, S.J., R.G. Menzel, E.D. Rhoades, J.R. Williams, and H.V. Eck. 1983. Nutrient and sediment discharge from Southern Plains grasslands. J. Range Manage. 36:435-439.
SPS. 2000. Cattle-feeding capital of the world, 2000 fed cattle survey. Southwestern Publ. Serv. Co., Amarillo, Tex..

Whitfield, C.J., J.H. Jones, and J.P. Baker. 1949. Grazing studies on the Amarillo Conservation Experiment Station. Texas Agr. Exp. Sta. Bull. 717.

Willis, W.W. 1995. Use of cattle feedlot manure and composted manure as an alternative source of nitrogen and phosphorus fertilizer in southern High Plains dryland agriculture. M.S. thesis, West Texas A\&M Univ., Canyon, Tex. 